\title{
Drug Target Insights
}

\section{Predictors of Virologic Failure in HIVIAIDS Patients Treated with Highly Active Antiretroviral Therapy in Brasília, Brazil During 2002-2008}

\author{
Edson José Monteiro Bello ${ }^{1}$, Amabel Fernandes Correia ${ }^{2}$, José Ricardo Pio Marins ${ }^{3}$, \\ Edgar Merchan-Hamann ${ }^{4}$ and Luis Isamu Barros Kanzaki ${ }^{5}$
}

${ }^{1}$ M.Sc. in Health Sciences, Nucleus of Virology, ${ }^{2}$ M.Sc in Health Sciences Nucleus of Parasitology, Central Public Health Laboratory, Brasilia, DF, Brazil, CEP 70830-010. ${ }^{3}$ Ph.D Secretary of State for Health, Federal District, Central Public Health Laboratory, Federal District, Brasília, DF, Brazil, CEP 70058-900. ${ }^{4}$ Ph.D Departament of Public Health, Faculty of Health Sciences, ${ }^{5}$ D.Sc. Laboratory of Bioprospection, University of Brasilia, Brasília, DF, Brazil, CEP 70910-900. Corresponding author email: Kanzaki@unb.br

\begin{abstract}
Little data exists concerning the efficacy of the antiretroviral therapy in the Federal District in Brazil, therefore in order to improve HIV/AIDS patients' therapy and to pinpoint hot spots in the treatment, this research work was conducted. Of 139 HIV/AIDS patients submitted to the highly active antiretroviral therapy, 12.2\% failed virologically. The significant associated factors related to unresponsiveness to the lentiviral treatment were: patients' place of origin $(\mathrm{OR}=3.28 ; \mathrm{IC} 95 \%=1.0-9.73 ; P=0.032)$ and $\mathrm{Myco}$ bacterium tuberculosis infection $(\mathrm{RR}=2.90$; IC95\% $=1.19-7.02 ; P=0.019)$. In the logistic regression analysis, the remaining variables in the model were: patients' birthplace $(\mathrm{OR}=3.28 ; \mathrm{IC} 95 \%=1.10-9.73 ; P=0.032)$ and tuberculosis comorbidity $(\mathrm{OR}=3.82$; IC95\% $=1.19-12.22 ; P=0.024)$. The patients enrolled in this survey had an $88.0 \%$ therapeutic success rate for the maximum period of one year of treatment, predicting that $\mathrm{T} \mathrm{CD}^{+}$low values and elevated viral loads at pretreatment should be particularly considered in tuberculosis coinfection, besides the availability of new antiretroviral drugs displaying optimal activity both in viral suppression and immunological reconstitution.
\end{abstract}

Keywords: antiretroviral therapy, tuberculosis coinfection, Brasilia, epidemiology

Drug Target Insights 2011:5 33-41

doi: $10.4137 / D T I . S 7527$

This article is available from http://www.la-press.com.

(C) the author(s), publisher and licensee Libertas Academica Ltd.

This is an open access article. Unrestricted non-commercial use is permitted provided the original work is properly cited. 


\section{Introduction}

Plasmatic viral load strongly predicts $\mathrm{T} \mathrm{CD}^{+}$cell count decline, AIDS progression and death. Anyway, disease prognosis in HIV infected subjects is more rigorously defined by the combination of plasmatic viral load quantification and $\mathrm{T} \mathrm{CD} 4^{+}$cell count. ${ }^{1}$ It is internationally noted that the main predictive factors for failure of antiretroviral therapy are $\mathrm{T} \mathrm{CD}^{+}$ cells low count and elevated viral load before commencing treatment. ${ }^{2}$ The efficacy of the Highly Active Antiretroviral Therapy (HAART) and the pattern of therapy management could be evaluated based on plasmatic RNA viral load assessement. In HIV/AIDS treatment the response is considered successful when the HIV RNA levels remain undetectable by certified commercial assays, notwithstanding in a variable proportion of HAART submitted patients, the viral replication and evolution goes on which could eventually contribute to the development of antiretroviral drug resistance and therapeutic failure. ${ }^{3}$

Unsuccessful antiretroviral therapy could occur due to virologic and immunologic failure and clinical manifestations that can appear during the course of HIV infection. The identification of therapeutic failure is based on patient follow-up during treatment, taking into account the initial level of $\mathrm{TCD}^{+}$, plasmatic HIV RNA load and the patient clinical evolution. Also, many factors could be related to therapeutic failure such as low treatment adhesion, insufficient drug dosage, mal-absorption, HIV antiretroviral resistance and drug interactions that could reduce the efficacy and HIV resistance to antiretroviral medications. Patients that failed to respond to antiretroviral therapy confirmed by the genotype resistant assay will be guided to choose new drugs. This choice is based on the knowledge of previous treatments and yet the reason to remove a drug from the antiretroviral regimen is mainly justified by the in vitro antiretroviral resistance profile. The antiretroviral therapeutic suspension as an alternative therapy is based on the reemergence of the initial virus population before treatment initiation, which would be susceptible to the antiretroviral drugs earlier prescribed, so this proposal is presently under evaluation. The essential objective of treatment in patients presenting therapeutic failure is to maintain $\mathrm{T} \mathrm{CD}^{+}$acceptable cell population density, whilst new therapeutic options are awaited, contrary to the priority aim to reach and keep up an undetectable viral load. ${ }^{4}$ According to Moore et al, ${ }^{5}$ virological failure is characterized by viral load higher than 400 copies/mL after 48 weeks of initial treatment or among subjects that had complete viral suppression, but later on the viral load will recrudesce. The viral failure precedes the immunologic failure which is defined by a decline of more than $25.0 \%$ in the subsequent count of $\mathrm{T} \mathrm{CD}^{+}$lymphocytes or regresion to the initial $\mathrm{T} \mathrm{CD} 4^{+}$cell count before treatment. These conditions are mainly suggestive of immunologic failure but laboratory analysis confirmation is mandatory. ${ }^{6}$ Cozzi-Lepri et $\mathrm{al}^{7}$ concluded that patients remaining in HAART failure presented viral load slowly progressing during the next 12 months, differently to $\mathrm{T}$ $\mathrm{CD}^{+}$cell count which remained stable.

The impact of HAART on $\mathrm{T} \mathrm{CD}^{+}$cell count and viral load of HIV infected patients has been demonstrated to improve the patient's immunological status and it also diminished the viral load, interrupting the AIDS progression. ${ }^{8}$ However there are crucial limitations of HAART regimen, as it does not eradicate viral infection despite long and permanent antiretroviral therapy. Consequently, a significant number of these patients on HAART therapy develop viral resistance to the drugs besides diverse side effects including metabolic disorders. Therefore new approaches are necessary to control and/or eradicate HIV infection. ${ }^{9,10}$

This research work aimed to analyze $\mathrm{T} \mathrm{CD}^{+}$ cell density and viral load response in HIV infected patients undergoing different therapeutic regimens which failed virologically, and also the associated factors to it during 2002-2008 in Brasilia, Federal District, Brazil.

\section{Material and Methods Patients}

A cohort study was conducted in the Health Center Number 01 attached to the Secretary of Health, Federal District (SES/DF) (Centro de Saúde Número 01, Secretaria de Saúde do Distrito Federal) which included 139 HIV-1 infected patients. The patients had clinical and laboratory diagnosis as defined by the 1993 AIDS clinical course criteria and by the US Center for Disease Control (CDC) ${ }^{11}$ and also by the recommendations of the Brazilian Consensus of Antiretroviral Therapy in Infected Adults and Adolescents by the Ministry of Health, Secretary of 
Health Surveillance, Brazilian National Program of Sexually Transmitted Diseases and AIDS. ${ }^{12}$ Patients selected for the study were identified in the records of Logistic System of the Ministry of Health, SICLOM ${ }^{13}$ utilized by the Hospital Dia, SES/DF.

The plasmatic HIV RNA load was quantified by the BDNA system 340 presenting sensitivity of less than 50 copies $/ \mathrm{mL}$. The T CD4+ helper lymphocytes' count was carried out by automatized flow cytometry utilizing the FacScalibur Count ${ }^{\circledR}$ System. The sampling utilized for patient selection was by convenience whose inclusion criteria were: (a) age higher than 18 years old and of both sexes; (b) HIV infection diagnosis defined by the Brazillian Ministry of Health standardized patterns; (c) detectable viral load previous to HAART beginning $>400$ copies $/ \mathrm{mL}$; (d) $\mathrm{T} \mathrm{CD}^{+}$ cell count $<500$ cells $/ \mathrm{mm}^{3}$ before HAART regimen initiation; (e) present laboratory analysis for viral load and $\mathrm{T} \mathrm{CD} 4^{+}$count between 6 and 12 months in order to compare the former ones with those of baseline; (f) patients have had clinical and immunological follow up during 3 months intervals.

If undetectable viral load of 50 copies $/ \mathrm{mL}$ was not sustained during 24 weeks of treatment or higher than 400 copies/mL after 48 weeks treatment, it was considered virological failure to the initial antiretroviral therapeutic regimen. ${ }^{5}$ Immunological failure was considered by the declining of T CD $4^{+}$cell counting $\geq 25.0 \%$ of the absolute values ${ }^{6}$ or by returning to the $\mathrm{T} \mathrm{CD} 4^{+}$cell count initial values before antiretroviral therapy initiation.

The viral load previous to HAART regimen initiation and $\mathrm{T} \mathrm{CD} 4^{+}$cell count were evaluated as possible predictors of viral failure leading us to establish the cut off values to viral load $>100.000$ copies $/ \mathrm{mL}$ or $\leq 100.000$ copies $/ \mathrm{mL}$ as also T CD4 $4^{+}>200$ cells $/ \mathrm{mm}^{3}$ or $\leq 200$ cells $/ \mathrm{mm}^{3}$.

The antiretroviral therapy regimen were: (a) double with two nucleoside reverse transcriptase inhibitor and non nucleoside reverse transcriptase inhibitor; (b) triple with two nucleoside reverse transcriptase inhibitor and one protease inhibitor and (c) three nucleoside reverse transcriptase inhibitor, according to CDC classification and the Brazilian Ministry of Health guidelines as previously described. In the population here studied, the chosen antiretroviral regimen was decided by the physician in charge without interference by the authors of this research work.
The criteria for the diagnosis of Hepatitis B and C virus infection followed the guidelines established by the Manual of Viral Hepatitis Consultancy, Secretary of Health Surveillance, Department of Epidemiological Surveillance, Brasília, Ministry of Health ${ }^{14}$ and also for the tuberculosis diagnosis, the Technical Manual for Tuberculosis Control, Notebook of Basic Attention, Secretary of Health Politics, Department of Basic Attention, Brasília. Ministry of Health. ${ }^{15}$

The exclusion criteria for this research were: (a) be pregnant or minor under 18 years old; (b) be prescribed with medications which could metabolically interact with antiretroviral drugs, including phytotherapics; (c) have had last clinical appointment in a period longer than 6 months which was considered lost to follow-up.

The analysis of baseline characteristics (initial data previous to initiation of treatment referring to $T$ $\mathrm{CD}^{+}$cell count and viral load) included frequency tables of categorical variables and their descriptive statistics (median, arithmetic mean and standard deviation) as also as continuous variables. In order to measure the dependent association between two categorial variables it was utilized the Chi-square test $\left(x^{2}\right)$ or when necessary the exact Fisher test. To compare before and after results the MacNemar test was applied. For the analysis of logistic regression and to predict the event of virological failure ${ }^{16}$ (depedent variable), the WALD method was applied. The association measurement calculated from the logistic model is the adjusted odds ratio (OR). The statistical analysis was carried out utilizing SPSS 17.0. The statistical association was considered when $P<0.05$.

The patients' data were confidential and consentment to utilize information were obtained at the Health Center Number 01 direction according to the Federal District Secretary (SES/DF) of Health agreement. The research work protocol was approved by the Federal District Secretary of Health Researh Ethics Committee, Foundation of Teaching and Research in Health Sciences (FEPECS).

\section{Results and Discussion}

Initially, 165 patients were eligible to participate in the study for starting the treatment in the period 2002-2008. However, only 139 patients met the inclusion criteria. Among them (Table 1A and B), 
Table 1A. Distribution of socioeconomic and demographic profiles of patients attended at Health Center No. 1 (Hospital Dia) during 2002-2008.

\begin{tabular}{|c|c|c|c|}
\hline Variable & Category & $\mathbf{N}$ & $\%$ \\
\hline \multirow[t]{2}{*}{ Sex } & Male & 103 & 74.1 \\
\hline & Female & 36 & 25.9 \\
\hline \multirow[t]{2}{*}{ Age } & $20-40$ & 68 & 48.9 \\
\hline & $41-65$ & 71 & 51.1 \\
\hline \multirow{3}{*}{$\begin{array}{l}\text { Race/ethnical } \\
\text { background }\end{array}$} & White & 60 & 43.2 \\
\hline & Mestizo & 76 & 54.6 \\
\hline & Black & 3 & 2.2 \\
\hline \multirow[t]{5}{*}{ Marital status } & Single & 67 & 48.2 \\
\hline & Married & 41 & 29.5 \\
\hline & Stable & 18 & 12.9 \\
\hline & Separate & 10 & 7.2 \\
\hline & Widow & 3 & 2.2 \\
\hline \multirow[t]{8}{*}{ Education } & $\begin{array}{l}\text { Incomplete elementary } \\
\text { schooling }\end{array}$ & 28 & 20.1 \\
\hline & $\begin{array}{l}\text { Complete elementary } \\
\text { schooling }\end{array}$ & 24 & 17.3 \\
\hline & $\begin{array}{l}\text { Middle incomplete } \\
\text { schooling }\end{array}$ & 19 & 7.2 \\
\hline & $\begin{array}{l}\text { Middle complete } \\
\text { schooling }\end{array}$ & 36 & 25.9 \\
\hline & $\begin{array}{l}\text { Incomplete higher } \\
\text { schooling }\end{array}$ & 4 & 2.9 \\
\hline & $\begin{array}{l}\text { Complete college } \\
\text { schooling }\end{array}$ & 27 & 19.4 \\
\hline & Illiterate & 9 & 6.5 \\
\hline & Not informed & 1 & 0.7 \\
\hline Total & & 139 & 100.0 \\
\hline
\end{tabular}

Source: SICLOM (MS-Brazil).

males predominated (74.1\%). Ages ranged from $20-65$ years old $($ mean $=39.7$ years, median $=40.0$ ). There was a slight predominance of patients in the range of 41-65 years old (51.1\%) compared to younger patients. As for race/ethnical background, there was a predominance of mestizos $(54.6 \%)$. Regarding to the marital status, there was a predominance of single people (48.2\%). High school education (25.9\%) predominated over other categories. People living in Taguatinga (13.7\%), a satellite city located in the surrounding areas of Brasília, represented the majority of the patients enrolled in this study. The place of birth showed that patients predominated from the Midwest (40.3\%) and the Northeast of Brazil (34.5\%). Hetrosexual relationships predominated $(51.8 \%)$, followed by the homosexual relationships (23.7\%).

The initial viral load ranged between 1.643 copies $/ \mathrm{mL}$ to 500.000 copies $/ \mathrm{mL}$ (mean $=180.721$ copies $/ \mathrm{mL}$; arithmetic mean $=126.417$ copies $/ \mathrm{mL}$ )
Table 1B. Distribution of socioeconomic and demographic profile of patients attended in the Health Center No. 1 (Hospita Dia) during 2002-2008.

\begin{tabular}{llll}
\hline Variable & Category & N & \% \\
\hline Residence & Pilot Plan & 29 & 20.9 \\
& Guara & 16 & 11.5 \\
& Ceilandia & 17 & 12.2 \\
& Taguatinga & 19 & 13.7 \\
& Bandeirante & 9 & 6.5 \\
& Gama & 14 & 10.0 \\
& Sobradinho & 3 & 2.2 \\
& Planaltina & 4 & 2.9 \\
& San Sebastian & 7 & 5.0 \\
& Paranoa & 2 & 1.4 \\
Birthplace & Around Brasília & 19 & 13.7 \\
& North & 4 & 2.9 \\
& Northeast & 48 & 34.5 \\
& South & 4 & 2.9 \\
& Southeast & 25 & 18.0 \\
& Midwest & 56 & 40.3 \\
Exposure category & African continent & 2 & 1.4 \\
& Accident at work & 1 & 0.7 \\
& Bisexual & 23 & 16.7 \\
& Heterosexual & 72 & 51.8 \\
& Homosexual & 33 & 23.7 \\
& Blood transfusion & 1 & 0.7 \\
& UDI & 9 & 6.6 \\
& & 139 & 100 \\
\hline & & & \\
& & &
\end{tabular}

Source: SICLOM (MS-Brazil).

Abbreviation: UDI, User injecting drug.

presenting more than half of the patients $(55.4 \%)$ cell density higher than 100.000 copies/mL (Table 2 ). After antiretroviral therapy, the initial profile changed substantially more than $70 \%$ of the patients had viral load lower than 50 copies $/ \mathrm{mL}$. In reference to the initial $\mathrm{T} \mathrm{CD}^{+}$cell count, $68.3 \%$ of the patients were in the range of $0-200$ cells $/ \mathrm{mm}^{3}$. After treatment a relevant change was observed in the patients profile concerning $\mathrm{T} \mathrm{CD}^{+}$cell counts, remaining less than $37 \%$ of the cases in this stage. In the following cell density interval, there was an expressive increment in the number of cases, representing more than $43.0 \%$ of the patients (Table 2 ). Initially the most utilized antiretroviral regimen included two drugs, the nucleoside reverse transcriptase inhibitor and non nucleoside reverse transcriptase inhibitor in $71.2 \%$ of the cases and the remaining $28.1 \%$ included two nucleoside reverse transcriptase inhibitor and one protease inhibitor. During the course of the treatment, the presented regimen distribution slightly changed to $66.9 \%$ to the first drug combination and 
Table 2. Viral load and T CD4+ cell counts distribution in 139 patients submitted to antiretroviral therapy in the Health Center No. 1 (Hospital Dia) during 2002-2008.

\begin{tabular}{llll}
\hline Variable & Category & $\mathbf{N}$ & $\%$ \\
\hline Initial viral load (treatment-naive) & $<50 \mathrm{copies} / \mathrm{mL}$ & 0 & 0 \\
& $50.1-400 \mathrm{copies} / \mathrm{mL}$ & 0 & 0 \\
& $400.1-10,000 \mathrm{copies} / \mathrm{mL}$ & 5 & 3.6 \\
& $10,000.1-100,000 \mathrm{copies} / \mathrm{mL}$ & 57 & 41.0 \\
Viral load after HAART & $100,0000.1-500,000 \mathrm{copies} / \mathrm{mL}$ & 77 & 55.4 \\
& $-50 \mathrm{copies} / \mathrm{mL}$ & 99 & 71.2 \\
& $50.1-400 \mathrm{copies} / \mathrm{mL}$ & 20 & 14.4 \\
& $400.1-10,000 \mathrm{copies} / \mathrm{mL}$ & 10 & 7.2 \\
& $10,000.1-100,000 \mathrm{copies} / \mathrm{mL}$ & 8 & 5.8 \\
Initial T CD4+ cell counts (treatment-naive) & $100,000-500,000 \mathrm{copies} / \mathrm{mL}$ & 2 & 1.4 \\
& $0-200 \mathrm{cells} / \mathrm{mm}^{3}$ & 96 & 68.4 \\
& $200.1-350 \mathrm{cells} / \mathrm{mm}^{3}$ & 37 & 26.6 \\
T CD4+ cell counts after HAART & $351-500 \mathrm{cells} /$ & 7 & 5.0 \\
& above de $500 \mathrm{cells} / \mathrm{mm}^{3}$ & 0 & 0 \\
& $0-200 \mathrm{cells} / \mathrm{mm}^{3}$ & 51 & 36.7 \\
HAART & $200.1-350 \mathrm{cellls} / \mathrm{mm}^{3}$ & 60 & 43.2 \\
& $351-500 \mathrm{cells} / \mathrm{mm}^{3}$ & 21 & 15.1 \\
& above de $500 \mathrm{cells} / \mathrm{mm}^{3}$ & 7 & 5.0 \\
& 2 ITRN +1 ITRNN & 99 & 71.2 \\
& 2 ITRN $+1 \mathrm{IP}$ & 39 & 28.1 \\
& 3 ITRN & 1 & 0.7 \\
& & 139 & 100 \\
\hline
\end{tabular}

Abbreviations: HAART, highly active antiretroviral therapy; NRTI, nucleoside reverse transcriptase inhibitor; NNRTI, non-nucleoside reverse transcriptase inhibitor.

$32.4 \%$ to the second one, there remaining only one utilizing three nucleoside reverse transcriptase inhibitor (Table 2).

Virologic failure was $12.2 \%$ (Table 3), or antiretroviral treatment success was $88.8 \%$, exceeding the results obtained by Johnson and Way of $80 \% .^{17}$ Among the socioeconomic and demographic variables, just the birthplace and the fact that originating in the Midwest Region which includes the Federal District, was associated with the occurrence of virologic failure in the study. Cole et al ${ }^{18}$ stated that HIV infection is sufficiently widespread, suggesting that it is a multidimensional epidemic, with demographic, residential, social, biological and behavioral significance. Perhaps this is a natural social structural marker as the study was conducted in the Midwest region compared to those migrating people from other regions to the Federal District. There was a trend toward a higher incidence of virologic failure being male, over 40 years old, mestizo, unmarried or separate and also heterossexual exposure category. However, there was not any statistical significance of such associations. It was found that only the birthplace presented statistical significance. Patients from the Midwestern had 2.7 times greater risk of virologic failure than those from other regions of Brazil, especially because the study was conducted in Brasilia, which is part of this region.

In this study, the initial viral load is not statistically associated and significant to the occurrence of virologic failure. However, there is the presence of a higher incidence of virologic failure among those who had viral load greater than 100.000 copies $/ \mathrm{mL}$ after the introduction of HAART. The virologic target for patients on HAART is to achieve viral load plasma levels below 50 copies $/ \mathrm{mL}$ when two or more potent drugs are used. These results highlight the importance of compliance with primary success and reinforces the need to work on the accession of such patients. Some authors ${ }^{19}$ interpret and agree that those with viral load higher than the baseline level of 100.000 copies $/ \mathrm{mL}$ had a slower pace to achieve viral suppression. However, a potent and well tolerated prophylactic regimen with HAART can improve $\mathrm{CD}^{+} \mathrm{T}$ cell count at the beginning, during and after treatment. Kantor et $\mathrm{al}^{2}$ concluded 
Table 3. Distribution of variables, viral load, T CD4+ cell counts, HAART and comorbidity in relation to the significance of virologic failure in patients treated at the Health Centre No. 1 (Hospital Dia) during 2002-2008.

\begin{tabular}{|c|c|c|c|c|c|c|c|}
\hline Variable & Category & VF & $\mathbf{N}$ & $\mathrm{Cl} \%$ & $\mathbf{R R}$ & $\mathrm{Cl} 195 \%$ & $P$ \\
\hline \multirow[t]{2}{*}{ Sex } & Male & 103 & 14 & 13.6 & 1.63 & $0.49-5.35$ & 0.407 \\
\hline & Female & 36 & 3 & 8.3 & & & \\
\hline \multirow[t]{2}{*}{ Age } & $41-65$ & 60 & 10 & 16.7 & 1.88 & $0.76-4.75$ & 0.164 \\
\hline & $20-40$ & 79 & 7 & 8.9 & & & \\
\hline \multirow[t]{2}{*}{ Race } & Mestizo & 79 & 10 & 12.7 & 1.08 & $0.43-2.68$ & 0.860 \\
\hline & White & 60 & 7 & 11.7 & & & \\
\hline \multirow[t]{2}{*}{ Marital status } & Single/separate & 80 & 11 & 13.8 & 1.35 & $0.53-3.44$ & 0.524 \\
\hline & Married/stable union & 59 & 6 & 10.2 & & & \\
\hline \multirow[t]{2}{*}{ Education } & NF incomplete/illiterate & 38 & 6 & 15.8 & 1.45 & $0.57-3.64$ & 0.432 \\
\hline & Other school levels & 101 & 11 & 10.9 & & & \\
\hline \multirow[t]{2}{*}{ Residence } & Brasilia suroundings & 19 & 3 & 15.8 & 1.35 & $0.42-4.27$ & 0.610 \\
\hline & Pilot plan/satellite city & 120 & 14 & 11.7 & & & \\
\hline \multirow[t]{2}{*}{ Birthplace } & Midwest & 56 & 11 & 19.6 & 2.71 & $1.06-6.92$ & 0.028 \\
\hline & North, northeast, south, southeast & 83 & 6 & 7.2 & & & \\
\hline \multirow[t]{2}{*}{ Exposury category } & Heterosexual & 83 & 11 & 13.3 & 1.23 & $0.48-3.15$ & 0.654 \\
\hline & Homosexual & 56 & 6 & 10.7 & & & \\
\hline
\end{tabular}

Abbreviations: $\mathrm{N}$, patients number; $\mathrm{VF}$, virological failure; $\mathrm{Cl}$, incidence coefficient; RR, relative risk; IC95\%, interval confidence; $P$, significance: NF, Uninformed.

that plasma viral load strongly predicts the rate of $\mathrm{CD}^{+}$lymphocyte count decrease, progression to AIDS and death. But the prognosis for people infected with HIV is more strictly defined by the combination of plasma viral load measurement and CD4 ${ }^{+}$lymphocytes' counts.

Some patients with viral load higher than 100.000 copies/mL remained in treatment failure after HAART regimen in contrast to $\mathrm{T} \mathrm{CD}^{+}$lymphocyte counts decrease at a slower pace, leaving some in virologic failure, probably due to the emergence of HIV resistant strains. Cozzi-Lepri et $\mathrm{al}^{7}$ advocate that patients who remained in HAART regimen failure, the viral load in the next twelve months was growing at a relatively slow pace, the $\mathrm{CD}^{+} \mathrm{T}$ cell count was stable and the time course of viral replication in patients with virological failure

Table 4. Distribution of association of viral load, T CD4 ${ }^{+}$cell count, HAART and comorbidities in terms of the significance of virologic failure in patients treated at the Health Centre No. 1 during the years 2002 to 2008.

\begin{tabular}{|c|c|c|c|c|c|c|c|}
\hline Variable & Category & $\mathbf{N}$ & VF & IC\% & $\mathbf{R R}$ & IC95\% & $P$ \\
\hline \multirow[t]{2}{*}{ Viral load after HAART } & $>100.000$ & 77 & 10 & 13.0 & 1.15 & $0.46-2.84$ & 0.762 \\
\hline & $\leq 100.000$ & 62 & 7 & 11.3 & & & \\
\hline \multirow[t]{2}{*}{ T CD4+ cell after HAART } & $>200$ & 95 & 8 & 10.5 & 0.66 & $0.27-1.63$ & 0.368 \\
\hline & $\leq 200$ & 44 & 9 & 15.9 & & & \\
\hline \multirow[t]{2}{*}{ HAART } & 2 ITRN + 1 ITRNN & 100 & 12 & 12.0 & 0.93 & $0.35-2.48$ & 0.804 \\
\hline & 2 ITRNN + 1 IP & 39 & 5 & 12.8 & & & \\
\hline \multirow[t]{2}{*}{ HCV (HCV-anti) } & Positive & 10 & 1 & 10.0 & 0.80 & $0.11-3.47$ & 0.823 \\
\hline & Negative & 129 & 16 & 12.4 & & & \\
\hline \multirow[t]{2}{*}{ HBV (HBsAg) } & Positive & 31 & 3 & 9.7 & 0.74 & $0.22-2.43$ & 0.623 \\
\hline & Negative & 108 & 14 & 13.9 & & & \\
\hline \multirow[t]{2}{*}{ TB (BAAR) } & Positive & 22 & 6 & 27.3 & 2.90 & $1.19-7.02$ & 0.019 \\
\hline & Negative & 117 & 11 & 10.3 & & & \\
\hline Total & & 139 & 17 & & & & \\
\hline
\end{tabular}

Abbreviations: HAART, antiretroviral therapy; $\mathrm{T}$ CD4+, lymphocyte count; $\mathrm{N}$, number of patients; VF, virologic failure values; Cl, incidence rate; $\mathrm{RR}$, relative risk; IC95\%, confidence interval; $P$, significance; HCV, antibody to the hepatitis "C" virus; HBV, antibody against hepatitis "B" virus antigens; TB, tuberculosis; BAAR, Alcohol acid resistant bacilli. 
Table 5. Logistic regresion in patients attended in the Health Center No. 1 (Hospital Dia) from 2002 to 2008.

\begin{tabular}{lllllll}
\hline Step & Variable & $\boldsymbol{\beta}$ & Wald test & $\boldsymbol{P}$-value & Odds ratio & IC95\% \\
\hline Step 1 & Gender & 1.142 & 1.718 & 0.182 & 3.132 & $0.586-16.746$ \\
& Age & 0.894 & 1.906 & 0.167 & 2.444 & $0.687-8.692$ \\
& Skin colour & 0.059 & 0.007 & 0.932 & 1.061 & $0.274-4.107$ \\
& Marital status & 0.512 & 0.588 & 0.443 & 1.668 & $0.451-6.170$ \\
& Education & 0.745 & 1.129 & 0.288 & 2.106 & $0.533-8.319$ \\
& Zone & 0.149 & 0.034 & 0.854 & 1.160 & $0.237-5.683$ \\
& Birthplace & 1.240 & 3.656 & 0.056 & 3.454 & $0.969-12.310$ \\
& Expsosure category & 0.580 & 0.475 & 0.491 & 1.786 & $0.343-9.301$ \\
& Viral load after HAART & 21.291 & 0.000 & 1.000 & 0.000 & $0.000-0.000$ \\
& T CD4+after HAART & 0.451 & 0.417 & 0.518 & 1.569 & $0.400-6.156$ \\
& HAART & -0.112 & 0.023 & 0.880 & 0.894 & $0.207-3.851$ \\
& HBV (HBsAg) & $-0,539$ & 0,210 & 0,647 & 0,583 & $0,058-5,859$ \\
& HCV (anti HCV) & -0.356 & 0.191 & 0.662 & 0.701 & $0.142-3.450$ \\
& TB (B.A.A.R.) & 1.107 & 2.536 & 0.111 & 3.025 & $0.775-11.810$ \\
Step 14 & Constant & -48.150 & 0.000 & 1.000 & 0.000 & $0.000-0.000$ \\
& Age & 0.812 & 2.125 & 0.145 & 2.252 & $0.756-6.707$ \\
& Birthplace & 1.308 & 5.247 & 0.022 & 3.698 & $1.208-11.322$ \\
& TB (B.A.A.R.) & 1.311 & 4.786 & 0.029 & 3.710 & $1.146-12.008$ \\
Paso 15 & Constant & -3.508 & 4.353 & 0.037 & 0.030 & $0.000-0.000$ \\
& Birthplace & 1.188 & 4.584 & 0.032 & 3.280 & $1.106-9.731$ \\
& TB (B.A.A.R.) & 1.340 & 5.098 & 0.024 & 3.820 & $1.194-12.229$ \\
& Constant & -2.173 & 2.567 & 0.109 & 0.114 & $0.000-0.000$ \\
\hline Abbrevitis & & & &
\end{tabular}

Abbreviations: $\beta$, maximum likehood values; HAART, antiretroviral therapy; CD4+, lymphocyte count; IC95\%, confidence interval; HCV, Hepatitis $C$ Virus: anti HCV, antibody to the hepatitis "C" virus; HBV, Hepatitis B Virus; HBsAg, Hepatitis B Virus surface antigen; TB, tuberculosis; B.A.A.R, Alcohol acid resistant bacilli.

had not been fully elucidated. Asjo and Langeland ${ }^{20}$ suggest that the lack of complete suppression of viral replication allows the continued development of HIV variants with different degrees of resistance. It results not only in treatment failure, but it also increases the risk of HIV primary resistance and dissemination.

Patients with initialCD4 ${ }^{+}$T cell count $\leq 200$ cells $/ \mathrm{mm}^{3}$ had a tendency to virologic failure, however, there was not any statistical significance. Tuberculosis coinfection was associated with virologic failure demonstrated with statistical significance, $P=0.019$. Patients with a previous diagnosis of tuberculosis infection had 2.9 times great risk of virologic failure.

It is observed that the T CD4 $4^{+}$cell count baseline above 200 cells $/ \mathrm{mm}^{3}$ was not statistically associated with virological failure, but the incidence of failure in this group was noticeably lower than in those with initial $\mathrm{T} \mathrm{CD}^{+}$less than 200 cells $/ \mathrm{mm}^{3}$. Studies conducted by Skowron et $\mathrm{al}^{21}$ demonstrated that $\mathrm{T}$ CD $4^{+}$ cell count is a better predictor of viral suppression. However, in order to achieve viral load suppression to undetectable levels, it is necessary to have an optimal response of $\mathrm{T} \mathrm{CD}^{+}$cell count in patients under antiretroviral therapy. Piliero ${ }^{22}$ comments that the maximum suppression of viral replication remains the primary goal of therapy after HAART regimen, therefore $\mathrm{T} \mathrm{CD}^{+}$cell count and HIV plasma viral load values are the prognostic markers for treatment success after four, eight or twelve weeks post treatment, as the changes are predictive of favorable longterm success in six months or more.

According to Moreno et $\mathrm{al}^{23}$ in multifailed patients, at least two active drugs can not be used, the therapeutic scheme should be kept in use until new drugs become available, assuming that there is an immunologic and clinical stability in order to avoid the use of a drug from a common chemical group which usually leads to a rapid viral resistance development, further limiting future treatment options. Geretti et $\mathrm{al}^{24}$ stated that patients in first HAART line who maintained consistently undetectable plasma viral load for a year, had a low risk of virologic failure.

In this study, the tuberculosis comorbidity had significant influence on the occurrence of virologic failure. Special attention should be given to early tuberculosis diagnosis during the early HAART 
regimen prescription. Studies reported by Bekker et $\mathrm{al}^{25}$ and von Reyn et $\mathrm{al}^{26}$ showed that the mycobacterial disease was a major contributor to HIV mortality. In addition, the infection increases the risk of latent tuberculosis reactivation, a new infection progression or re-infection to active disease, increasing the risk of the emergence of HIV resistant strains to the usual antiretroviral therapy. Tuberculosis also accelerates the course of HIV induced disease by activating viral replication and accentuating the decline of T $\mathrm{CD} 4^{+}$cells.

In the logistic regresion analysis the best model to explain the event of virological failure is the one that includes variables such as origin and infection by $M$. tuberculosis, yielding OR values of 3.2 and 3.8 respectively.

\section{Conclusion}

Despite the enormous progress as a result of the impact of HAART-related morbidity and mortality in patients with HIV/AIDS continue and will continue to fail in the face of the therapeutic classes of HAART currently available. The presented results reinforce the importance of monitoring the biological markers $\mathrm{T} \mathrm{CD} 4^{+}$cells and viral load in patients living with and without AIDS, both to ensure that viral replication is under control and to reassure the maintenance of immune reconstitution compatible with life, and to predict the risk of developing resistance and therapeutic failures in the course of the treatment of HIV-infected people.

It should be noted that the sample size limited the analysis of this study, as the retrospective information taken from the medical records, excluded some data from the laboratory and the clinical follow up. The sample obtained in this way may have had a limited ability to highlight the predictive differences of risk for both $\mathrm{T} \mathrm{CD}^{+}$cell count and viral load in naive patients. It is possible that working with a larger cohort of patients and longer follow-up of these predictors probably would show more consistent evidence that is statistically supported. Initial treatment with any NNRTI-based regimen or an IP, but not both, is a good strategy for managing the long-term antiretroviral treatment in naive HIV patients. Moreover, the recent availability of new antiretroviral agents for the treatment of HIV has increased treatment options and improved durability, tolerability and efficacy in the long-term HAART regimen.

Other limitations that should be highlighted refer to the possibility of verifying the association of HBV and HCV coinfections which do not have evolutionary studies of these HIV comorbidities. It is possible that if we had a homogeneous group of patients already in advanced stages of these pathologies, the risk of virologic failure would be high. The sociodemographic data were collected from medical records and not through interviews, this fact may also have skewed the results of the analysis of association between these variables and treatment failure. However, this service data and variables accounted are limitations imposed by real situations in nosocomial institutions in the Federal District in Brazil.

It is of great relevance to the findings in this study considering the limitations and difficulties of conducting studies in routine service, as it can be concluded that even in the non-ideal conditions of a clinical trial, patients treated in this unit had virological success of $12.2 \%$ up to one year of treatment, a fact that can predict the durability of the first scheme which is better than expected in many other international centers. ${ }^{17}$ Also tuberculosis infection should be traced as a priority as early as possible. As the low values of T $\mathrm{CD}^{+}$ cell counts and high viral load pre-treatment should be considered to implement the prescribed antiretroviral therapy, especially when new classes are available and have superior performance, as much viral suppression and immune reconstitution could be achieved.

\section{Disclosures}

Author(s) have provided signed confirmations to the publisher of their compliance with all applicable legal and ethical obligations in respect to declaration of conflicts of interest, funding, authorship and contributorship, and compliance with ethical requirements in respect to treatment of human and animal test subjects. If this article contains identifiable human subject(s) author(s) were required to supply signed patient consent prior to publication. Author(s) have confirmed that the published article is unique and not under consideration nor published by any other publication and that they have consent to reproduce any copyrighted material. The peer reviewers declared no conflicts of interest. 


\section{References}

1. Mellors JW, Munoz A, Giorgi JV, Margolick JB, Tassoni CJ, Gupta P. Plasma viral load and $\mathrm{CD}^{+}$lymphocytes as prognostic markers of HIV-1 infection. Ann Intern Med. Jun 15, 1997;126(12):946-54.

2. Kantor R, Diero L, Delong A, Kamle L, Muyonga S, Mambo F. Misclassification of first-line antiretroviral treatment failure based on immunological monitoring of HIV infection in resource-limited settings. Clin Infect Dis. Aug 1, 2009;49(3):454-62.

3. Pasternak AO, Adema KW, Bakker M, Jurriaans S, Berkhout B, Cornelissen M. Highly sensitive methods based on seminested real-time reverse transcription-PCR for quantitation of human immunodeficiency virus type 1 unspliced and multiply spliced RNA and proviral DNA. J Clin Microbiol. Jul 2008;46(7):2206-11.

4. Pinganaud C, Goujard C. Management of antiretroviral treatment in HIV-infected patients exhibiting virologic failure. Presse Med. Jun 22, 2002;31(22):1034-40.

5. Gallant JE. Drug resistance after failure of initial antiretroviral therapy in resource-limited countries. Clin Infect Dis. Feb 1, 2007;44(3):453-5.

6. Turner BJ, Hecht FM, Ismail RB. $\mathrm{CD}^{+}$T-lymphocyte measures in the treatment of individuals infected with human immunodeficiency virus type 1. A review for clinical practitioners. Arch Intern Med. Jul 25, 1994;154(14):1561-73.

7. Cozzi-Lepri A, Phillips AN, Miller V, Katlama C, Ledergerber B, Vella S. Changes in viral load in people with virological failure who remain on the same HAART regimen. Antivir Ther. Apr 2003;8(2):127-36.

8. Resino S, Bellon JM, Ramos JT, Resino R, Gurbindo MD, Mellado MJ. Impact of highly active antiretroviral therapy on $\mathrm{CD} 4^{+} \mathrm{T}$ cells and viral load of children with AIDS: a population-based study. AIDS Res Hum Retroviruses. Sep 2004;20(9):927-31.

9. Battegay M, Fehr J, Fluckiger U, Elzi L. Antiretroviral therapy of late presenters with advanced HIV disease. J Antimicrob Chemother. Jul 2008; 62(1):41-4.

10. Melchior R, Nemes MI, Alencar TM, Buchalla CM. Challenges of treatment adherence by people living with HIV/AIDS in Brazil. Rev Saude Publica. Dec 2007;41 Suppl 2:87-93.

11. CDC revises HIV classification system, AIDS definition. $W V M e d J$. Feb 1993;89(2):74.

12. Brazil MoH, Secretariat of Health Surveillance, National STD and AIDS. Recommendations for antiretroviral therapy in adults and adolescents infected with HIV. 2008. Available: http://bvsms.saude.gov.br/bvs/ publicacoes/recomendacao_terapia.pdf access: 28/05/2011.

13. Brazil MoHSSoH, National STD AIDS. Quick Reference for the ARV Drug Dispensing SICLOM. 2007. Available: http://siclom.aids.gov.br access: 28.05.2011.

14. Brazil NPfPaCoVH. National Program for Prevention and Control of Viral Hepatitis. 2005. National Program for Prevention and Control of Viral Hepatitis http://bvsms.saude.gov.br/bvs/politicas/hepatites_aconselhamento.pdf access: 28.05.2011.

15. Brazil MoH, Department of health Policy, Department of Primary Care. Technical Manual for the Control of Tuberculosis. 2002. Available to: http:// bvsms.saude.gov.br/bvs/publicacoes/guia_controle_tuberculose.pdf access: 28.05.2011.

16. Faucher JF, Challier B, Chirouze C, Drobacheff C, Fischer P, Lang JM. Predictive factors of virological response to primary antiretroviral treatment. Presse Med. Mar 13, 2004;33(5):310-5.

17. Johnson K, Way A. Risk factors for HIV infection in a national adult population: evidence from the 2003 Kenya Demographic and Health Survey. J Acquir Immune Defic Syndr. Aug 15, 2006;42(5):627-36.

18. Cole SR, Hernan MA, Anastos K, Jamieson BD, Robins JM. Determining the effect of highly active antiretroviral therapy on changes in human immunodeficiency virus type 1 RNA viral load using a marginal structural leftcensored mean model. Am J Epidemiol. Jul 15, 2007;166(2):219-27.

19. Phillips AN, Staszewski S, Weber R, Kirk O, Francioli P, Miller V. HIV viral load response to antiretroviral therapy according to the baseline CD4 cell count and viral load. JAMA. Nov 28, 2001;286(20):2560-7.
20. Asjo B, Langeland N. Drug resistance in HIV infection. Tidsskr Nor Laegeforen. Nov 20, 2008;128(22):2593-6.

21. Skowron G, Street JC, Obee EM. Baseline CD4(+) cell count, not viral load, correlates with virologic suppression induced by potent antiretroviral therapy. J Acquir Immune Defic Syndr. Dec 1, 2001;28(4):313-9.

22. Piliero PJ. Early factors in successful anti-HIV treatment. J Int Assoc Physicians AIDS Care (Chic Ill). Jan-Mar 2003;2(1):10-20.

23. Moreno Cuerda VJ, Rubio Garcia R, Morales Conejo M. New therapeutic options in protracted HIV-infected patients with virological failure. Med Clin (Barc). Jan 26, 2008;130(2):66-70.

24. Geretti AM, Smith C, Haberl A, Garcia-Diaz A, Nebbia G, Johnson M. Determinants of virological failure after successful viral load suppression in first-line highly active antiretroviral therapy. Antivir Ther. 2008;13(7): 927-36.

25. Bekker LG, Orrell C, Reader L, Matoti K, Cohen K, Martell R. Antiretroviral therapy in a community clinic - early lessons from a pilot project. $S$ Afr Med J. Jun 2003;93(6):458-62.

26. von Reyn CF, Kimambo S, Mtei L, et al. Disseminated tuberculosis in human immunodeficiency virus infection: ineffective immunity, polyclonal disease and high mortality. Int J Tuberc Lung Dis. Aug 2011;15(8):1087-92.

\section{Publish with Libertas Academica and every scientist working in your field can read your article}

"I would like to say that this is the most author-friendly editing process I have experienced in over 150 publications. Thank you most sincerely."

"The communication between your staff and me has been terrific. Whenever progress is made with the manuscript, I receive notice. Quite honestly, l've never had such complete communication with a journal."

"LA is different, and hopefully represents a kind of scientific publication machinery that removes the hurdles from free flow of scientific thought."

\section{Your paper will be:}

- Available to your entire community free of charge

- $\quad$ Fairly and quickly peer reviewed

- Yours! You retain copyright 